\title{
Acute nickel carbonyl poisoning: a report of 179 cases
}

\author{
SHI ZHICHENG \\ From the Department of Occupational Medicine, Third Hospital, Beijing Medical University, Beijing, China
}

Since 1961, 179 cases of acute nickel carbonyl poisoning in China have been collected and the clinical findings are presented in this paper.

\section{General data}

SEX, AGE, AND CAUSES OF INTOXICATION There were $122(68 \cdot 2 \%)$ male patients and $57(31 \cdot 8 \%)$ female, and their ages ranged from 18 to 53 .

The causes of intoxication included (1) accidental spills or leaks of nickel carbonyl liquid or vapour from apparatus or tubes, (2) feed in raw material, (3) checking and repairing of the apparatus and tubes, and (4) fire fighting. Accidental spills or leaks were the commonest cause.

\section{AIR CONCENTRATION}

According to some samples, the air concentration of $\mathrm{Ni}(\mathrm{CO})_{4}$ exceeded $50 \mathrm{mg} / \mathrm{m}^{3}$ and the air concentration of $\mathrm{CO}$ ranged from $118.3 \mathrm{mg} / \mathrm{m}^{3}$ to $1462 \cdot 6 \mathrm{mg} / \mathrm{m}^{3}$.

\section{CONTACT TIME}

Fifty nine cases $(32.9 \%)$ had exposure lasting less than 30 minutes, $51(28.5 \%)$ one hour, $48(26.8 \%)$ one to two hours, and $21(11.7 \%)$ more than two hours.

\section{TIME OF ONSET}

In 74 cases $(41 \cdot 3 \%)$ symptoms appeared within 30 minutes to one hour, some within five minutes, and in 67 cases $(37.5 \%)$ symptoms appeared within one to four hours. In the other 38 cases $(21 \cdot 2 \%)$ onset was delayed for a week.

\section{Clinical observations}

The symptoms and signs noted in the patients are listed in tables 1 and 2 . The most frequent symptoms were referred to the respiratory and nervous systems. Symptoms and signs typical of toxic pulmonary oedema or chemical pneumonia, or both, were present in six severe cases, and of toxic myocarditis in three cases.

Accepted 23 September 1985
LABORA TOR Y STUDIES

Leukocytosis was found in 25 cases $(14 \cdot 0 \%)$, values ranging from 12000 to $23000 / \mathrm{mm}^{3}$ with a shift to the left. Leukocytosis was found in parallel with the severity of the intoxication. No eosinophilia were found. SGPT levels were slightly increased in six cases $(3.4 \%)$ but returned to normal within three weeks. The urine nickel concentration was determined in $27 \%$ cases $(16.3 \%)$ and ranged from $0.003 \mathrm{mg} / \mathrm{l}$ to $\underset{\mathrm{N}}{\mathrm{N}}$ $0.66 \mathrm{mg} / \mathrm{l}$. The maximum excretion of nickel in the urine occurred one to two days after the onset of intoxication and returned to normal after one week.

\section{ECG FINDINGS}

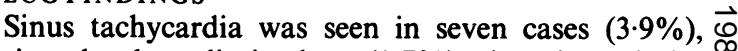
sinus bradycardia in three $(1.7 \%)$, sinus irregularity with or without heart block in five $(2.8 \%)$, premature ventricular contraction in two $(1 \cdot 1 \%)$, and myocardial injury in eight $(4.5 \%)$, including toxic myocarditis in three (changes in S-T and T wave, Q-T time was prolonged).

\section{RADIOGRAPHIC FEATURES}

Increasing irregular linear shadows were seen in 16 cases $(8.9 \%)$, including four with expansion and increased density of the hilus. Diffuse irregular nodular mottling or patchy shadows were seen in the lung fields in four cases $(2.2 \%)$, pulmonary oedema in two $(1 \cdot 1 \%)$, and pleural fluid effusion in two.

\section{TREATMENT AND PROGNOSIS}

Mild cases were treated with rest in bed after removal from exposure. Bronchodilators and symptomatic 옥 drugs were also given. Oxygen, glucose, vitamin $C, \underset{D}{D}$ and corticosteroids were also administered in moderate cases. In severe cases we used a series of drugs $N$ and methods, such as limitation of water intake, administration of oxygen, hibernation therapy, and parenteral administration of large doses of corti- $\omega$ costeroid, Dithiocarb, antibiotics, and other drugs to help resolve pulmonary oedema, pneumonia, and 0 toxic myocarditis.

All the patients recovered and had no severe $\stackrel{\mathscr{f}}{?}$ sequelae, but about one third had a neurasthenic syndrome and weakness after discharge. In some cases these symptoms persisted for three to six months. 
Table 1 Clinical symptoms of acute nickel carbonyl poisoning

\begin{tabular}{|c|c|c|c|c|c|c|c|c|}
\hline & \multicolumn{2}{|c|}{$\begin{array}{l}\text { Mild cases } \\
(n=148)\end{array}$} & \multicolumn{2}{|c|}{$\begin{array}{l}\text { Moderate cases } \\
(n=25)\end{array}$} & \multicolumn{2}{|c|}{$\begin{array}{l}\text { Severe cases } \\
(n=6)\end{array}$} & \multicolumn{2}{|c|}{$\begin{array}{l}\text { Total } \\
(n=179)\end{array}$} \\
\hline & No & $\%$ & No & $\%$ & No & $\%$ & No & $\%$ \\
\hline \multicolumn{9}{|l|}{ Respiratory system: } \\
\hline Chest tightness and pain & 90 & $60 \cdot 8$ & 25 & $100 \cdot 0$ & 6 & $100 \cdot 0$ & 121 & $67 \cdot 6$ \\
\hline Dryness in the throat & 60 & $40 \cdot 5$ & 13 & $52 \cdot 0$ & 5 & $33 \cdot 3$ & 78 & $43 \cdot 6$ \\
\hline Cough & 26 & 17.6 & 14 & 56.0 & 5 & $83 \cdot 3$ & 45 & $25 \cdot 1$ \\
\hline Sore throat & 12 & $8 \cdot 1$ & 8 & $30 \cdot 0$ & 4 & $66 \cdot 6$ & 16 & 8.9 \\
\hline Difficulty with breathing & 5 & $3 \cdot 4$ & 16 & 62.0 & 6 & $100 \cdot 0$ & 27 & $15 \cdot 1$ \\
\hline Haemoptysis & 2 & 1.4 & 0 & 0 & 1 & $16 \cdot 7$ & 3 & 1.7 \\
\hline Expectoration & 1 & 0.7 & 5 & $20 \cdot 0$ & 5 & $83 \cdot 3$ & 11 & $6 \cdot 2$ \\
\hline Frothy sputum & 1 & 0.7 & 2 & $8 \cdot 0$ & 3 & $50 \cdot 0$ & 6 & 3.4 \\
\hline Dyspnoea & 0 & 0 & 10 & $40 \cdot 0$ & 6 & $100 \cdot 0$ & 16 & 8.9 \\
\hline \multicolumn{9}{|l|}{ Nervous system: } \\
\hline Dizziness & 98 & $66 \cdot 2$ & 25 & $100 \cdot 0$ & 6 & $100 \cdot 0$ & 129 & $72 \cdot 1$ \\
\hline Headache & 69 & $46 \cdot 6$ & 22 & 88.0 & 6 & $100 \cdot 0$ & 97 & $54 \cdot 2$ \\
\hline Sleeplessness & 15 & $10 \cdot 0$ & 10 & $40 \cdot 0$ & 3 & $50 \cdot 0$ & 28 & $15 \cdot \overline{6}$ \\
\hline Dysphoria & 8 & $5 \cdot 4$ & 3 & $12 \cdot 0$ & 5 & $83 \cdot 3$ & 16 & 8.9 \\
\hline Blurred vision & 3 & $2 \cdot 0$ & 7 & $28 \cdot 0$ & 3 & $50 \cdot 0$ & 13 & $7 \cdot 3$ \\
\hline Somnolence & 3 & $2 \cdot 0$ & 5 & $20 \cdot 0$ & 1 & $16 \cdot 7$ & 9 & $5 \cdot 1$ \\
\hline Numbness & 2 & $1 \cdot 3$ & 4 & $16 \cdot 0$ & 1 & $16 \cdot 7$ & 7 & 3.9 \\
\hline \multicolumn{9}{|l|}{ Digestive system: } \\
\hline Nausea & 84 & $56 \cdot 8$ & 25 & $100 \cdot 0$ & 6 & $100 \cdot 0$ & 115 & $64 \cdot 2$ \\
\hline Loss of appetite & 22 & 14.9 & 7 & $28 \cdot 0$ & 6 & $100 \cdot 0$ & 35 & $19 \cdot 6$ \\
\hline Vomiting & 4 & $2 \cdot 7$ & 6 & $24 \cdot 0$ & 3 & 50.0 & 13 & $7 \cdot 3$ \\
\hline Abdominal pain & 1 & 0.7 & 1 & $4 \cdot 0$ & 1 & $16 \cdot 7$ & 3 & 1.7 \\
\hline \multicolumn{9}{|l|}{ Others: } \\
\hline Weakness & 71 & $48 \cdot 0$ & 21 & $84 \cdot 0$ & 6 & $100 \cdot 0$ & 98 & 54.8 \\
\hline Palpitation & 21 & $14 \cdot 1$ & 9 & $36 \cdot 0$ & 3 & 50.0 & 33 & 18.4 \\
\hline Cold sweat & 12 & $8 \cdot 1$ & 7 & $28 \cdot 0$ & 3 & $50 \cdot 0$ & 22 & $12 \cdot 4$ \\
\hline Intolerance of cold & 9 & $6 \cdot 1$ & 11 & $44 \cdot 0$ & 1 & $16 \cdot 7$ & 7 & 3.9 \\
\hline Fever & 2 & 1.4 & 4 & $16 \cdot 0$ & 1 & 16.7 & 12 & $6 \cdot 7$ \\
\hline
\end{tabular}

On average, the recovery time was seven days in mild cases, 18 days in moderate cases, and $\mathbf{4 0}$ days in severe cases.

\section{Discussion}

Nickel carbonyl $\left(\mathrm{Ni}(\mathrm{CO})_{4}\right)$ is a liquid metal compound of considerable toxicity. By inhalation the $\mathrm{LC}_{50}$ to $\mathrm{LC}_{100}$ for laboratory animals ranges from $100 \mathrm{mg} \mathrm{Ni}(\mathrm{CO})_{4} / \mathrm{m}^{3}$ for a 20 minute exposure in the rat to $190 \mathrm{mg} / \mathrm{m}^{3}$ for a 30 minute exposure in the cat and to $2500 \mathrm{mg} / \mathrm{m}^{3}$ in the $\operatorname{dog} .^{1}$ The pathology of lesions in the lungs of rats and dogs after acute inhalation shows pulmonary congestion and oedema, interstitial pneumonitis with focal atelectasis, and necrosis. $^{2}$

Sunderman and Vuopala have given a detailed description of acute nickel carbonyl poisoning in man. ${ }^{34}$ The acute toxic effects occur in two stages, immediate and delayed. In the present study the immediate toxic effect was predominantly manifested by neurological symptoms and irritation of the upper respiratory tract. The cases who had only immediate symptoms were considered as mild.

Table 2 Clinical signs of acute nickel carbonyl poisoning

\begin{tabular}{|c|c|c|c|c|c|c|c|c|}
\hline & \multicolumn{2}{|c|}{$\begin{array}{l}\text { Mild cases } \\
(n=148)\end{array}$} & \multicolumn{2}{|c|}{$\begin{array}{l}\text { Moderate cases } \\
(n=25)\end{array}$} & \multicolumn{2}{|c|}{$\begin{array}{l}\text { Severe cases } \\
(n=6)\end{array}$} & \multicolumn{2}{|c|}{$\begin{array}{l}\text { Total } \\
(n=179)\end{array}$} \\
\hline & No & $\%$ & No & $\%$ & No & $\%$ & No & $\%$ \\
\hline $\begin{array}{l}\text { Hyperaemia of the conjunctiva } \\
\text { Hyperaemia of the throat } \\
\text { Cyanosis } \\
\text { Raucous breath sounds } \\
\text { Wheezing } \\
\text { Dry rales } \\
\text { Moist rales } \\
\text { Tachycardia } \\
\text { Tachypnoea } \\
\text { Arrhythmia } \\
\text { High blood pressure } \\
\text { Hepatic signs }\end{array}$ & $\begin{array}{r}58 \\
19 \\
0 \\
7 \\
1 \\
3 \\
0 \\
11 \\
7 \\
1 \\
10 \\
7\end{array}$ & $\begin{array}{l}39 \cdot 2 \\
12 \cdot 8 \\
0 \\
4 \cdot 7 \\
0 \cdot 7 \\
2 \cdot 0 \\
0 \\
7 \cdot 4 \\
4 \cdot 7 \\
0 \cdot 7 \\
6 \cdot 8 \\
4 \cdot 7\end{array}$ & $\begin{array}{r}21 \\
6 \\
5 \\
7 \\
1 \\
8 \\
0 \\
8 \\
3 \\
1 \\
3 \\
2\end{array}$ & $\begin{array}{r}84 \cdot 0 \\
24 \cdot 0 \\
20 \cdot 0 \\
28 \cdot 0 \\
4 \cdot 0 \\
32 \cdot 0 \\
0 \\
32 \cdot 0 \\
12 \cdot 0 \\
4 \cdot 0 \\
12 \cdot 0 \\
8 \cdot 0\end{array}$ & $\begin{array}{l}3 \\
6 \\
5 \\
0 \\
0 \\
4 \\
4 \\
2 \\
6 \\
1 \\
1 \\
1\end{array}$ & $\begin{array}{c}50 \cdot 0 \\
100 \cdot 0 \\
83 \cdot 3 \\
0 \\
0 \\
66 \cdot 7 \\
66 \cdot 7 \\
33 \cdot 3 \\
100 \cdot 0 \\
16.7 \\
16.7 \\
16.7\end{array}$ & $\begin{array}{r}82 \\
31 \\
10 \\
14 \\
2 \\
15 \\
4 \\
21 \\
16 \\
3 \\
14 \\
10\end{array}$ & $\begin{array}{r}45 \cdot 8 \\
17 \cdot 3 \\
5 \cdot 5 \\
7.8 \\
1.1 \\
8.4 \\
2.2 \\
11.7 \\
8.9 \\
1.7 \\
7.8 \\
5.6\end{array}$ \\
\hline
\end{tabular}


In moderate cases the delayed stage was characterised by the appearance of symptoms such as chest pain, cough, dyspnoea, vomiting, palpitations, intolerance to cold, fever with leukocytosis, and some $x$ ray abnormalities.

All six severe cases had pulmonary oedema or pneumonitis or both and three had toxic myocarditis which does not appear to have been reported before.

The direct toxic effect of $\mathrm{Ni}(\mathrm{CO})_{4}$ and $\mathrm{CO}$ on the heart-an impairment in lung function, relative lack of oxygen, and an increased load on the heart-all probably play a part in the production of this toxic myocarditis.

Our experience also showed that prompt help (first aid) and comprehensive treatment are important for the recovery of the patients and that severe sequelae are unlikely. In addition, we also confirmed that corticosteroids are useful and helpful drugs in these cases.

\section{References}

${ }^{1}$ Sunderman FW. Nickel poisoning I. Experimental study of the effects of acute and subacute exposure to nickel carbonyl. Arch Ind Hyg Occup Med 1953;8:48.

${ }^{2}$ Hackett RL, Sunderman FW. Acute pathological reactions to ad- $C$ ministrations of $\mathrm{Ni}(\mathrm{CO})_{4}$. Arch Environ Health 1967;14:604-13.

${ }^{3}$ Sunderman FW. Nickel poisoning II. Studies on patients suffering from acute exposure to vapors of nickel carbonyl. JAMA 1954;155:889.

${ }^{4}$ Vuopala VE. Nickel carbonyl poisoning. Report of 25 cases. Ann Clin Res 1970;2:2114.

\section{Vancouver style}

All manuscripts submitted to the $B r J$ Ind Med should conform to the uniform requirements for manuscripts submitted to biomedical journals (known as the Vancouver style).

The $\mathrm{Br} J$ Ind Med, together with many other international biomedical journals, has agreed to accept articles prepared in accordance with the Vancouver style. The style (described in full in $\mathrm{Br}$ Med J, 24 February 1979, p 532) is intended to standardise requirements for authors.

References should be numbered consecutively in the order in which they are first mentioned in the text by Arabic numerals above the line on each occasion the reference is cited (Manson' confirmed other reports ${ }^{2-5} \ldots$..). In future references to papers submitted to the $\mathrm{Br} J$ Ind Med should include: the names of all authors if there are six or less or, if there are more, the first three followed by et al; the title of journal articles or book chapters; the titles of journals abbreviated according to the style of Index Medicus; and the first and final page numbers of the article or chapter.

Examples of common forms of references are:

I International Steering Committee of Medical Editors. Uniform requirements for manuscripts submitted to biomedical journals. Br Med J 1979; 1:532-5.

2 Soter NA, Wasserman SI, Austen KF. Cold urticaria: release into the circulation of histamine and eosinophil chemotactic factor of anaphylaxis during cold challenge. $N$ Engl J Med 1976;294:687-90.

' Weinstein L, Swartz MN. Pathogenic properties of invading micro-organisms. In: Sodeman WA Jr, Sodeman WA, eds. Pathologic physiology: mechanisms of disease. Philadelphia W B Saunders, 1974:457-72. 